\title{
Green Buying Behavior Using Theory of TPB in Online Shop in Medan City
}

\author{
Eka Dewi Setia Tarigan ${ }^{1 *}$,Yuni Syah Putri ${ }^{2}$, Hesti Sabrina ${ }^{3}$ \\ ${ }^{1,2,3}$ Department of Management, Faculty of Economics and Busines, Universitas Medan Areas \\ Medan, North Sumatera, Indonesiia. \\ ${ }^{*}$ Corresponding Author: \\ Email: aprilsitepu@ymail.com
}

\begin{abstract}
.
Awareness of environmental responsibility in order to build a sustainable business makes marketers realize the importance of nurturing green consumers. The community now realizes the importance of green purchasing behavior in order to realize responsible behavior to preserve the environment. In this new normal era, people also purchase green products online. The research uses the TPB (Theory of Planned Behavior) theory proposed by Ajzen. This study discusses how the behavior of green online shop consumers in Medan city. The variables in this study are green consumer behavior. variable attitude, subjective norm and perceived behavior control. In the new normal era, the questionnaire was distributed and answered via google form to 100 respondents. From the processing of multiple linear regression analysis, it was found that the variable attitude and subjective norm had a positive and significant effect on green consumer behavior, and the variable perceived behavior control had no effect on green consumer behavior on online shops in Medan.
\end{abstract}

Keywords: Consumer behavior, green, online shop

\section{INTRODUCTION}

The issue of global warming threatens environmental sustainability and results in climate change. Global warming has made the world community, including Indonesia, strive to preserve the environment and climate change. Due to the increase in population in Indonesia, the issue of waste in 2020 will reach 67.8 million tons (https://news.detik.com/berita/d-5046558/menteri-lhk-timbunan-sampah-di-indonesia-tahun-020 -reach-678million-ton). This problem has become the center of public attention because a preserved environment will strengthen a sustainable ecosystem. The public realizes the importance of maintaining the environmental ecosystem, such as participating in various event programs in the green consumer awareness movement. The current government is also increasingly aggressively advising the public to be aware of environmental ecosystems. Therefore, now people in Indonesia have realized awareness in preserving the environment and its ecosystem. With this environmental awareness movement, it is hoped that the damage to nature will not become more widespread. The environmental awareness movement that has become increasingly lively lately has led to public concern for environmental preservation which is manifested in consumer behavior in choosing products and companies that can maintain a sustainable environment

As a result of this environmental damage, the community seeks to reduce global warming climate change by consuming environmentally friendly products, such as reducing grocery plastics, the movement for greening tree plants, using basic materials for products that do not damage the environment, products that can be recycled. Activities carried out by the community on a daily basis which seem trivial but contribute a great potential in environmental destruction, such as; use of plastic packaging that takes a long time to decompose, disposal of leftover food that is still fit for consumption, electronic waste which is very dangerous for the environment, use of microbeads or fine scrub facial cleansers that take years to decompose, consumption of animal meat excessive 
use of greenhouse gases, the increasing number of vehicles causes air pollution, excessive use of air conditioners which causes the effect of increasing greenhouse gases.

Today's consumers are expected to be more sensitive in consuming green products such as; reduce the use of products that damage the environment and switch to using environmentally friendly products, consuming products that can be used continuously, consuming products that can be recycled. Previous studies from various researchers in Indonesia discussed more about green consumer behavior in various industries but no one has specifically discussed green consumer behavior in online stores. Based on this, this study discusses how the behavior of green consumers in making decisions about purchases at online stores in Medan.

\section{METHOD}

In this study, the method used is associative with the type of quantitative research that uses the population of people in Medan who often shop using an online shop. Primary data is obtained from distributing questionnaires conducted to respondents through the google form application which is distributed online through notifications on social networks. Secondary data were obtained from several literature.

To prove the answer from the hypothesis, so multiple linear regression analysis tests were carried out through the $\mathrm{t}$ test and the $\mathrm{F}$ test. The table below is the result of multiple linear regression analysis data processing.

Tabel 1. Coefficients ${ }^{\mathrm{a}}$

\begin{tabular}{|c|c|c|c|c|c|c|}
\hline & \multirow[b]{2}{*}{ Model } & \multicolumn{2}{|c|}{$\begin{array}{l}\text { Unstandardized } \\
\text { Coefficients }\end{array}$} & \multirow{2}{*}{\begin{tabular}{|c}
$\begin{array}{c}\text { Standardize } \\
\mathrm{d} \\
\text { Coefficients }\end{array}$ \\
Beta
\end{tabular}} & \multirow[b]{2}{*}{$\mathrm{T}$} & \multirow[b]{2}{*}{ Sig. } \\
\hline & & B & Std. Error & & & \\
\hline \multirow[t]{4}{*}{1} & (Constant) & 13.664 & 2.593 & & 5.270 & .000 \\
\hline & Attitude & .365 & .079 & .464 & 4.640 & .000 \\
\hline & Subjective Norm & .243 & .106 & .268 & 2.302 & .023 \\
\hline & $\begin{array}{l}\text { PerceivedddBehavio } \\
\text { ur Control }\end{array}$ & .054 & .080 & .064 & .674 & .502 \\
\hline
\end{tabular}

a. Dependent Variable: Green Consumer Behaviour

Based on the table above, the regression equation formula can be obtained as follows: $\mathrm{Y}=(13,664)+$ $0.365 \mathrm{X} 1+0.243 \mathrm{X} 2+0.054 \mathrm{X} 3+\mathrm{e}$. The $\mathrm{t}$ test from the table above is to determine the effect of the attitude variable on green consumer behavior. From the table above, the t value of the variable Attitude (X1) is 0.4640 and the t table value with $\alpha 5 \%$ is 1.66 , thus the first hypothesis is that the attitude variable has a positive and significant effect on green consumer behavior online shops in Medan city with significant level $0.000<0.005$. The $\mathrm{t}$ value for variable subjective norm was obtained 2.302> 1.66. Thus, the second hypothesis was accepted, namely variable subjective norm has a positive and significant effect on the behavior variable of green online shop consumers in Medan. The $t$ value for the perceived behavior control variable is $0.054<1.66$, thus the third hypothesis is rejected, which means that the variable perceived behavior control has no effect on the green online shop consumer behavior variable in Medan.

Tabel.2 ANOVA ${ }^{\mathrm{a}}$

\begin{tabular}{|c|c|c|c|c|c|}
\hline Model & $\begin{array}{l}\text { Sum of } \\
\text { Squares }\end{array}$ & Df & $\begin{array}{l}\text { Mean } \\
\text { Square }\end{array}$ & $\mathrm{F}$ & Sig. \\
\hline $1 \quad$ Regression & 87.383 & 3 & 29.128 & 34.434 & $.000^{\mathrm{b}}$ \\
\hline
\end{tabular}




\begin{tabular}{|c|c|c|c|}
\hline Residual & 81.207 & 96 & .846 \\
\hline Total & 168.590 & 99 & \\
\hline
\end{tabular}

a. Dependent Variable: Green Consumer Behaviour

b. Predictors: (Constant), PerceivedddBehaviour Control, Attitude, Subjective

Norm

From the table, it is obtained that the $\mathrm{f}$ value is 34.434 and the $\mathrm{f}$ table value is 2.70 , which means that the four variables, namely attitude, subjective norm and perceived behavior have a positive effect with a significance value of 0.000 and $\alpha$ of $5 \%$. This shows that the variable attitude, subjective norm and perceived behavior control together have an influence on the green consumer behavior variable, thus the fourth hypothesis is accepted.

Tabel 3. Model Summary ${ }^{\mathrm{b}}$

\begin{tabular}{|l|r|r|r|r|r|}
\hline Model & \multicolumn{1}{|c|}{$\mathrm{R}$} & R Square & $\begin{array}{c}\text { Adjusted R } \\
\text { Square }\end{array}$ & $\begin{array}{c}\text { Std. Error of } \\
\text { the Estimate }\end{array}$ & Durbin-Watson \\
\hline 1 & $.720^{\mathrm{a}}$ & .518 & .503 & .920 & 2.222 \\
\hline
\end{tabular}

a. Predictors: (Constant), Behavioral Control, Attitude, Subjective Norm

b. Dependent Variable: Green consumer Behaviour

Based on the table above, the $\mathrm{R}$ value is 0.720 and $\mathrm{R} 2$ value is 0.518 and the adjusted $\mathrm{R}$ Square value is 0.503 which means that green consumer behavior is influenced by the variable attitude, subjective norm, and perceived behavior of 0.503 .

\section{RESULT DISCUSSION}

Based on the results of data processing from the table above shows the attitude variable has a positive and significant effect on green consumer behavior. This is different from the research conducted by Kristiana Sri Utami, the results of her research show that attitudes towards the environment have no effect on green consumer buying behavior, because consumers are more interested in those that can motivate and touch consumer awareness to behave green in consuming a product.

From the results of data processing for variable subjective norms have a positive and significant effect on green consumer behavior. This research is in line with the research conducted by YatishJosi and Zillur Rahman. In this study, theyexplain that subjective norm has a positive and significant effect on green online shop consumer behavior in Medan.Data processing from the table above shows that the variable perceived behavior has no effect on green consumer behavior. This research is in line with the research conducted by Shwu-Ing Wu1 \&Jia-Yi Chen which states that perceived behavior control has a positive and significant effect on consumer behavior in green online shop in Medan.

\section{CONCLUSION}

Based on discussion above, the following conclusions can be drawn: the attitude variable has a positive and significant effect with a $t$ value of 4.640> 1.66 ( $\mathrm{t}$ table) on the behavior of green online shop consumers in Medan. Subjective norm variable has a positive and significant effect with a t-count value of 2.302> 1.66 (t table) on the behavior of green online shop consumers in Medan. Meanwhile, the variable Perceived Behavior control has no effect on green consumer behavior of 0.674 <green consumer behavior. And testing simultaneously for the variable attitude. Subjective norm and perceived behavior control together influence the behavior of green online shop consumers in Medan. Thus, the company is expected to improve its green 
consumer behavior strategy. The writer suggests that the next researchers discuss the variables that affect attitude, subjective norm and perceived behavior control and add variables that can influence the buying behavior of green consumers.

\section{REFERENCES}

[1] Ajzen, I. (1991). The Theory of Planned Behavior. Organizational Behavior and Human Decision Processes, 50, 179-211. doi: 10.1016/0749- 5978(91)90020-T

[2] Bhutto, Muhammad Yaseen; Zeng, Fue; Soomro, Yasir Ali; Khan, Mussadiq Ali Young Chinese consumer decision making in buying green products: An application of theory of planned behavior with gender and price transparency. Pakistan Journal of Commerce and Social Sciences.Vol.13, Iss.3.ISSN 2309-8619.

[3] Chen, A., \& Peng, N. (2012).Green hotel knowledge and tourists' staying behavior.Annals of Tourism Research, 39(4), 2211-2216. http://doi.org/10.1016/j.annals.

[4] D'Souza, C., Taghian, M., Lamb, P., \&Peretiatkos, R. (2006). Green Products and Corporate Strategy: An Empirical Investigation", Society and Business Review, 1(2), 144-157.

[5] Fishbein, M, \&Ajzen, I.1975. Belief, Attitude, Intention, and Behavior: An Introduction to Theory and Research, Reading, MA: Addison-Wesley.

[6] Kim, Y., \& Han, H. (2010). Intention to pay conventional-hotel prices at a green hotel-amodification of the theory of planned behavior. Journal of Sustainable Tourism, 18(8), 997-1014.

[7] Krueger, N. and Carsrud, A. (1993). Entrepreneurial intentions: applying the theory of plannedbehavior. Entrepreneurship and Regional Development. Vol. 5, pp. 315-30.

[8] Kumar, B. (2012). Theory of Planned Behaviour Approach to Understand the Purchasing Behaviour for Environmentally Sustainable Products.Working paper.

[9] Leonard, M.,Graham,S.,Bonacum.,D.,2004.Thehumanfactor:thecriticalim- portance of effective team work and communication inproviding safe care. Qual. Saf.Health Care13,85-90.

[10] Maichun, K.,Surakiat P, and Ke-Chung.,P.(2016). Application of the extended theory of planned behavior model to investigate purchase intention of green products among Thai Consumer.Journal of sustainability.

[11] Mills, Rebecca M. Ag. 2012. What It Means to Go Green: Reduce, Reuse, Repurpose, and Recycle. Logan, Utah State University.

[12] Moisander, J., \&Pesonen, S. (2002). Narratives of Sustainable Ways of living: Constructing The Self and The Other As A Green Consumer. Journal Management Decision, 40(4), 329-342. Vol. 17 Nomor 2, Mei (2018) 101 Management Decision, 40(4), 329-342.

[13] Scypa, P. (2006). Lingkunganpemasarandanpovedeniepotrebitelskoe/Russian Markets. EkonomidanManajemen: Current Issues and Perspectives, 2 (7), 156-159

[14] Shabani, Nazanin, Mohboobeh, Ashoori, Mohammad, Taghinejad, HamedBeyrami, and Marjan N. Fekri. 2013. The Study of Green Consumers' Characteristics and Available Green Sectoris in The Market. International Research Journal of Applied and basic Science.ScienceExplorer.Pubication.

[15] Speer, M. (2011, December 9). What is a Green Product? Retrieved July 28, 2020, from http://www.isustainableearth.com/green-products/what-is-a-green-product 